\title{
HUBUNGAN ANTARA SIKAP ILMIAH DAN KECERDASAN EMOSIONAL TERHADAP PRESTASI BELAJAR IPA SISWA KELAS V SDN SEKECAMATAN KEBUMEN TAHUN AJARAN 2020/2021
}

\author{
Steffina Indri Hapsari ${ }^{1}$, Tri Saptuti Susiani ${ }^{2}$, Kartika Chrysti Suryandari ${ }^{3}$ \\ Universitas Sebelas Maret \\ steffinahapsari@gmail.com
}

\section{Article History \\ accepted 30/8/2021}

approved 30/9/2021 published 30/10/2021

\begin{abstract}
Scientific attitude and emotional intelligence are needed so that students have good science learning achievements and are able to compete in the times. The study aimed to know correlation between scientific attitudes and science learning achievement, to know correlation between emotional intelligence and science learning achievement, and to know correlation between scientific attitudes and emotional intelligence on science learning achievement for fifth grade students of public elementary schools in Kebumen Sub district in academic year of 2020/2021. The research was quantitative research including ex-pose facto and correlational method. The research results showed that the scientific attitudes had correlation on science learning achievement (Sig. $0.00<0.05$ ) with coefficient value 0.567, emotional intelligence had correlation on science learning achievement (Sig. $0.00<0.05$ ) with coefficient value 0.528 , and scientific attitudes and emotional intelligence had correlation on science learning achievement (Sig. $0.00<0.05$ ) with coefficient value 0.634 . It meant that the better students' scientific attitudes and the emotional intelligence, the better learning achievement.
\end{abstract}

Keywords: scientific attitude, emotional intelligence, learning achievement

\begin{abstract}
Abstrak
Sikap ilmiah dan kecerdasan emosional dibutuhkan agar siswa memiliki prestasi belajar IPA yang baik dan mampu bersaing dalam perkembangan zaman. Penelitian ini bertujuan mengetahui adanya korelasi sikap ilmiah dengan prestasi belajar IPA, korelasi kecerdasan emosional dengan prestasi belajar IPA, dan korelasi sikap ilmiah dan kecerdasan emosional dengan prestasi belajar IPA siswa kelas $V$ SDN se-Kecamatan Kebumen tahun ajaran 2020/2021. Penelitian ini merupakan penelitian kuantitatif dengan jenis expost facto dan metode korelasi. Hasil penelitian menunjukkan sikap ilmiah memiliki korelasi dengan prestasi belajar IPA (Sig. 0,00<0,05) dengan nilai koefisien korelasi 0,567, kecerdasan emosional memiliki korelasi dengan prestasi belajar IPA (Sig. 0,00<0,05) dengan nilai koefisien korelasi 0,528 , serta sikap ilmiah dan kecerdasan emosional memiliki korelasi dengan prestasi belajar IPA (Sig. $0,00<0,05$ ) dengan nilai koefisien korelasi 0,634. Semakin tinggi sikap ilmiah dan kecerdasan emlosional siswa secara bersama-sama, maka prestasi belajar IPA yang diperoleh juga akan semakin baik.
\end{abstract}

Kata kunci: sikap ilmiah, kecerdasan emosional, prestasi belajar

This work is licensed under a Creative Commons Attribution-ShareAlike 4.0 International License. 


\section{PENDAHULUAN}

Perkembangan ilmu pengetahuan dan teknologi di era globalisasi semakin hari semakin berkembang pesat. Pendidikan di abad 21 membutuhkan manusia yang dapat berpikir kritis dan mengusai teknologi. Kemampuan berpikir kritis menjadi tolak ukur manusia dalam menganalisis dan menyelesaikan suatu permasalahan yang terkait dengan perkembangan zaman. Sedangkan penguasaan teknologi merupakan suatu kemampuan yang harus dimiliki manusia karena segala kebutuhan di abad 21 memanfaatkan teknologi untuk memenuhi kebutuhan manusia. Namun pada kenyataannya, sumber daya manusia di Indonesia kurang mengimbangi adanya perkembangan zaman tersebut. Dengan demikian diperlukan wadah yang dapat mencetak sumber daya manusia yang dapat mengimbangi perkembangan zaman.

Usaha yang dilakukan pemerintah untuk meningkatkan sumber daya manusia yaitu dengan mewajibkan masyarakat untuk menempuh pendidikan dasar melalui pendidikan formal yaitu sekolah dasar dan menengah. Pembelajaran IPA masuk dalam kurikulum pendidikan dasar sampai menengah.

Menurut Kusumastuti, Rombot, dan Ariesta (2019) yang menyatakan, "Science education as a curriculum component must be able to provide a model for forming effective communication and decision making through cultural and linguistic differences". Yang artinya, pendidikan IPA sebagai komponen kurikulum harus mampu menyediakan suatu model untuk komunikasi yang efektif dan pengambilan keputusan atas perbedaa budaya dan bahasa. Adanya pembelajaran IPA harus dapat membuat siswa mampu mengambil berbagai keputusan atas permasalahan yang berkaitan dengan fenomena alam yang diamati saat pembelajaran berlangsung.

Suryantini, Sujana dan Wiarta (2018) berpendapat mengenai sikap ilmiah adalah sikap dalam diri siswa yang tidak dapat diajarkan melalui pembelajaran tertentu tetapi harus terus dikembangkan pada kegiatan sains untuk mendapatkan suatu ilmu pengetahuan yang berorientasi pada metode ilmiah. Sikap ilmiah yang dikembangkan dalam diri peserta didik akan membuat peserta didik memiliki perilaku positif untuk mendpatkan suatu ilmu pengetahuan. Siswa dengan yang memiliki sikap ilmiah akan berperilaku memecahkan masalah dengan pikiran terbuka, rasa ingin tahu dan sesuai dengan prosedur yang benar. Harlen (Fatonah dan Prasetyo, 2014) mengemukakan pengelompokkan sikap ilmiah, yaitu: (1) sikap ingin tahu; (2) sikap objektif terhadap data/fakta; (3) sikap berpikir kritis; (4) sikap penemuan dan kreativitas; (5) sikap berpikiran terbuka dan kerjasama; (6) sikap ketekunan; dan (7) sikap peka terhadap lingkungan sekitar.

Karakter sikap ilmiah tersebut sangat membantu dalam mengembangkan prinsipnya dan menerima sesuatu yang baru. Murugan (2019) berpendapat, "Scientific attitudes are the most important outcomes of science teaching. Through science teaching certain social ethics and values such as honesty, rationality, objectivity and making judgement based on reliable information can be developed in our students", artinya adalah sikap ilmiah adalah hasil terpenting pengajaran IPA. Melalui sains mengajarkan etika sosial tertentu dan nilai-nilai seperti kejujuran, rasionalitas, objektivitas, dan pembuatan penilaian berdasarkan informasi yang dapat diandalkan dapat dikembangkan siswa. Sikap ilmiah juga membantu siswa berprinsip terbuka dengan sesuatu yang baru sehingga keterampilan dan kemapuan siswa akan berkembang serta sikap ilmiah dapat mengembangkan sikap keterbukaan, objektif, dan jujur pada peserta didik sehingga siswa dapat berprestasi dan mempunya prestasi belajar yang baik.

Salovey dan Mayer (Wulansari, 2014) mendefinisikan kecerdasan emosi sebagai kemampuan mengendalikan perasaan sendiri dan orang disekitarnya, serta menggunakan perasaan tersebut untuk memandu pikiran dan tindakan. Kecerdasan emosional diperlukan agar seseorang dapat memotivasi diri sendiri dan mengendalikan perasaan dengan baik. dengan meningkatkan kecerdasan emosional, diperoleh dua manfaat yaitu: karakter tangguh dan prestasi belajar yang baik. Sejalan dengan 
Ebrahimi, Khoshsima, dan Behtash (2018) yang menyatakan bahwa, “...there is another influential factor in success which is Emotional Intelligence; states that IQ affords the 'floor' and Emotional Intelligence affords the 'ceiling' for success". Yang artinya, ada faktor lain yang berpengaruh dalam keberhasilan yaitu kecerdasan emosional, menyatakan bahwa IQ menyediakan 'dasar' dan EQ menjadikan 'langit-langit' dalam kesuksesan. Dengan kata lain, kedua inteligensi itu saling melengkapi. Keseimbangan antara $I Q$ dan $E Q$ berpengaruh terhadap keberhasilan belajar siswa di sekolah. Pendidikan di sekolah perlu mengembangkan emotional intelligence siswa. Goleman (2016) mengungkapkan ada 5 aspek kecerdasan emosional yaitu: (1) mengenali emosi diri; (2) mengelola emosi; (3) motivasi diri; (4) empati; dan (5) membina hubungan.

Kecerdasan yang mempengaruhi prestasi belajar tidak hanya kecerdasan intelektual namun ada pula kecerdasan emosional. Kecerdasan emosional (EQ) merupakan kemampuan individu dalam mengandalikan berbagai perasaan dan emosi sehingga dapat memandu pikiran dan tindakan untuk menyelesaikan berbagai persoalan dengan baik. Siswa yang memiliki kecerdasan emsional yang baik akan mampu memberikan keseimbangan pada kecerdasan intelektual (IQ) untuk memahami meteri pelajaran dan memberikan motivasi kepada diri sendiri untuk belajar serta mencari potensi sekaligus nilai-nilai yang ada dalam diri individu tersebut sehingga prestasi belajar yang diperoleh akan baik.

Prestasi belajar IPA juga dapat dipengaruhi oleh kedua faktor sekaligus, yaitu sikap dan kecerdasan. sikap yang berhubungan erat dengan pembelajaran IPA adalah sikap ilmiah. Kemudian kecerdasan yang dibutuhkan siswa dalam memperoleh prestasi belajar yang baik bukan hanya kecerdasan intelegensi tetapi juga dipengaruhi kecerdasan emosional. Siswa yang mempunyai sikap ilmiah dan kecerdasan emosional tidak akan kesulitan memperoleh prestasi belajar yang baik.

Tujuan penelitian ini mengetahui adanya (1) korelasi antara sikap ilmiah dengan prestasi belajar IPA; (2) korelasi antara kecerdasan emosional dengan prestasi belajar IPA; dan (3) korelasi antara sikap ilmiah dan kecerdasan emosional dengan prestasi belajar IPA siswa kelas V SDN se-Kecamatan Kebumen tahun ajaran 2020/2021.

\section{METODE}

Desain penelitian ini yaitu penelitian kuantitatif, jenis penelitian expost facto, dan metode penelitian korelasi. Jenis penelitian expost facto dilakukan jika peneliti yakin, perlakuan variabel telah terjadi sebelumnya (Lestari dan Yudhanegara, 2017). Jenis penelitian expost facto berlaku pada variabel $Y$ yaitu prestasi belajar IPA. Metode penelitian korelasi adalah penelitian yang melibatkan hubungan antara variabel atau beberapa variabel dengan variabel lain. Populasi penelitian ini yaitu siswa kelas V SDN seKecamatan Kebumen sejumlah 1554 siswa, sampel sebanyak 319 siswa, dan sampel yang diperoleh sebanyak 323 siswa di dua belas SDN di Kecamatan Kebumen. Teknik sampling yang digunakan yaitu cluster random sampling.

Teknik pengumpulan data penelitian ini menggunakan angket dan dokumentasi. Instrumen yang digunakan yaitu angket sikap ilmiah meliputi aspek ingin tahu, objektif terhadap data/fakta, berpikir kritis, penemuan dan kreativitas, berpikiran terbuka dan kerjasama, ketekunan, dan peka terhadap lingkungan sekitar. Kemudian angket kecerdasan emosional meliputi mengenali emosi diri, mengelola emosi, motivasi diri, empati, dan membina hubungan. Sedangkan dokumentasi digunakan untuk prestasi belajar IPA yaitu nilai rapot aspek kognitif siswa kelas V SD semester gasal tahun ajaran 2020/2021 kurikulum 2013.

Uji prasyarat data penelitian ini yaitu normalitas data, linieritas data, dan multikolinieritas data. Setelah data memenuhi prasyarat, data dianalisis menggunkan korelasi berganda dan koefisien determinan. 


\section{HASIL DAN PEMBAHASAN}

Penelitian dilakukan dengan memberikan angket sikap ilmiah dan angket kecerdasan emosional kepada siswa kelas V SD yang menjadi sampel penelitian. Uji prasyarat data penelitian ini telah terpenuhi yaitu data berdistribusi normal, data linier, dan tidak terjadi multikolinieritas pada variabel $X$.

Nilai signifikansi uji normalitas 0,121 untuk data sikap ilmiah, 0,375 untuk data kecerdasan emosional, dan 0,468 untuk data prestasi belajar IPA. Nilai signifikansi ketiga variabel tersebut menunjukkan lebih besar dari 0,05 , sehingga data dikatakan berdistribusi normal.

Nilai Sig. Deviation from Linearity untuk variabel sikap ilmiah terhadap prestasi belajar IPA adalah 0,171 dan variabel kecerdasan emosional terhadap prestasi belajar IPA adalah 0,688. Nilai Sig. Deviataion from Linearity menunjukkan $>(0,05)$. Oleh karena itu data penelitian ini bersifat linier.

Uji multikolinearitas menunjukkan bahwa nilai tolerance 0,753 dan nilai VIF 1,358 . Hal itu menunjukkan bahwa nilai tolerance $>0,10$ dan nilai VIF $<10,0$, sehingga dikatakan bahwa tidak terjadi multikolinieritas antarvariabel bebas pada penelitian ini.

Setelah uji prasyarat analisis data telah terpenuhi, selanjutnya dilakukan analisis data uji hipotesis.

Tabel 1. Hasil Uji Analisis Sikap IImiah (X1) dan Kecerdasan Emosional (X2) terhadap Prestasi belajar IPA (Y)

\begin{tabular}{|c|c|c|}
\hline Aspek & R (Person) & $\begin{array}{c}\text { KP } \\
\text { (koefisien } \\
\text { determinan) }\end{array}$ \\
\hline $\mathrm{X} 1$ terhadap $\mathrm{Y}$ & 0,567 & $32,2 \%$ \\
\hline$X 2$ terhadap $Y$ & 0,528 & $27,9 \%$ \\
\hline$X 1$ dan $X 2$ tehadap $Y$ & 0,634 & $40,2 \%$ \\
\hline
\end{tabular}

Analisis hipotesis pertama dalam penelitian ini yaitu terdapat korelasi antara sikap ilmiah terhadap prestasi belajar IPA siswa kelas V SDN se-Kecamatan Kebumen tahun ajaran 2020/2021.

Berdasarkan hasil analisis data, diperoleh nilai signifikansi sebesar $0,00<0,05$, artinya hipotesis penelitian ini dapat diterima. Jadi, dapat disimpulkan terdapat hubungan (korelasi) antara sikap ilmiah terhadap prestasi belajar IPA siswa kelas V SDN se-Kecamatan Kebumen tahun ajaran 2020/2021. Hasil tersebut sesuai dan relevan dengan penelitian yang dilakukan oleh Azhari, Suastra, dan Sudiatmika (2020) yang menunjukkan hasil penelitian yaitu sikap ilmiah memiliki hubungan yang terhadap prestasi belajar.

Dasta mengemukakan bahwa siswa yang mempunyai sikap ilmiah akan memiliki kelancaran dalam berpikir sehingga akan termotivasi untuk selalu berprestasi dan memiliki komitmen yang kuat untuk mencapai keberhasilan dan keunggulan dalam belajar (Suryani, 2016).

Uji korelasi berganda menunjukkan angka koefisien korelasi sebesar 0,567 yang menunjukkan angka koefisien positif artinya sikap ilmiah dan prestasi belajar IPA memiliki hubungan positif dengan kategori kuat. Uji korelasi yang dilakukan peraspek sikap ilmiah terhadap prestasi belajar IPA, diperoleh $r$ hitung $>r$ tabel dan diketahui nilai signifikansi sebesar 0,00 0,05 artinya terdapat hubungan antara ketujuh aspek sikap ilmiah terhadap prestasi belajar IPA. Kemudian, nilai koefisien korelasi ketujuh aspek menunjukkan angka korelasi positif yang artinya menunjukkan hubungan (korelasi) positif peraspek sikap ilmiah terhadap prestasi belajar IPA.

Hasil uji korelasi berganda tersebut sesuai dengan penelitian yang dilakukan oleh Khairawati, Rahayu, dan Setiadi (2018) yang menyatakan bahwa, sikap ilmiah memiliki hubungan yang positif dan sangat kuat terhadap prestasi belajar siswa. 
Hasil penelitian ini juga menunjukkan kontribusi yang dihasilkan sikap ilmiah terhadap prestasi belajar IPA melalui perhitungan koefisien determinan yaitu $32,2 \%$. Hasil koefisien determinan tersebut sejalan dengan penilitian yang telah dilakukan oleh Wicaksono dan Widyaningrum (2016) yang menyatakan bahwa sikap ilmiah memiliki kontribusi terhadap prestasi belajar IPA.

Analisis hipotesis kedua dalam penelitian ini yaitu terdapat korelasi antara kecerdasan emosional terhadap prestasi belajar IPA siswa kelas V SDN se-Kecamatan Kebumen tahun ajaran 2020/2021.

Berdasarkan hasil analisis data, diperoleh nilai signifikansi sebesar $0,00<0,05$, artinya hipotesis penelitian ini dapat diterima. Jadi, dapat disimpulkan terdapat hubungan (korelasi) antara kecerdasan emosional terhadap prestasi belajar IPA siswa kelas V SDN se-Kecamatan Kebumen tahun ajaran 2020/2021. Sesuai dengan penelitian yang dilakukan Thaib (2013), diperoleh hasil terdapat hubungan antara kecerdasan emosional terhadap prestasi belajar. Kecerdasan emosional dapat dinyatakan sebagai salah satu faktor penting yang seharusnya dimiliki oleh siswa untuk meraih prestasi belajar yang lebih baik di sekolah.

Eva dan Kusrini (2015) menyatakan bahwa kecerdasan emosi dapat dikatakan sebagai kemampuan mengendalikan perasaan sendiri dan orang disekitarnya, serta menggunakan perasaan tersebut untuk memandu pikiran dan tindakan dalam belajar.

Uji korelasi berganda menunjukkan hasil koefisien korelasi sebesar 0,528 yang menunjukkan angka korelasi positif artinya kecerdasan emosional dan prestasi belajar IPA memiliki hubungan positif dengan kategori kuat. Uji korelasi berganda peraspek kecerdasan emosional terhadap prestasi belajar IPA menunjukkan nilai $r$ hitung $>r$ tabel dan diketahui nilai signifikansi sebesar $0,00<0,05$ artinya terdapat hubungan (korelasi) antara kelima aspek kecerdasan emosional terhadap prestasi belajar IPA. Kemudian, nilai koefisien korelasi kelima aspek kecerdasan emosional menunjukkan angka korelasi positif yang artinya menunjukkan hubungan positif peraspek kecerdasan emosional terhadap prestasi belajar IPA.

Hasil uji korelasi berganda tersebut sesuai dengan penelitian yang dilakukan oleh Adnyana, Suma, dan Suswandi (2017) yang menunjukkan hasil hubungan yang positif antara kecerdasan emosional dan prestasi belajar.

Hasil penelitian ini juga menunjukkan kontribusi kecerdasan emosional terhadap prestasi belajar IPA melalui koefisien determinan yaitu 27,9\% sedangkan sisanya $72,1 \%$ ditentukan atau ada kontribusi dari variabel lain yang tidak diteliti. Relevan dengan penelitian hasil ang dilakukan oleh Jannah, Susanti, dan Benni (2016) yang menyatakan adanya kontribusi kecerdasan emosional terhadap prestasi belajar siswa.

Analisis hipotesis ketiga dalam penelitian ini yaitu terdapat korelasi antara sikap ilmiah dan kecerdasan emosional terhadap prestasi belajar IPA siswa kelas V SDN seKecamatan Kebumen tahun ajaran 2020/2021.

Berdasarkan hasil pengujian hipotesis menggunakan SPSS versi 21 menunjukkan bahwa nilai Sig. F Change sebesar 0,00 <0,05, artinya hipotesis penelitian ini dapat diterima. Jadi dapat disimpulkan bahwa terdapat hubungan (korelasi) antara sikap ilmiah dan kecerdasan emosional secara bersama-sama terhadap prestasi belajar IPA siswa kelas V SDN se-Kecamatan Kebumen tahun ajaran 2020/2021.

Hasil koefisien korelasi sebesar 0,634 menunjukkan bahwa yang menunjukkan angka korelasi positif artinya sikap ilmiah dan kecerdasan emosional terhadap prestasi belajar IPA memiliki hubungan positif dengan kategori kuat. Maka dapat dikatakan bahwa, semakin tinggi sikap ilmiah dan kecerdasan emosional siswa maka semakin tinggi juga prestasi belajar IPA siswa tersebut. Sesuai dengan penelitian yang dilakukan Ventini, Hartati, dan Sukardjo (2018) yang menunjukkan hasil keduanya sebagai faktor yang mempengaruhi hasil dan prestasi belajar menunjukkan hubungan yang positif terhadap prestasi belajar siswa. 
Hasil penelitian juga menunjukkan kontribusi sikap ilmiah dan kecerdasan emosional secara bersama-sama terhadap prestasi belajar IPA melalui koefisien determinan yaitu $40,2 \%$ sedangkan sisanya $59,8 \%$ ditentukan atau ada kontribusi dari variabel lain yang tidak diteliti.

\section{SIMPULAN}

Berdasarkan hasil penelitian dapat ditarik kesimpulan sebagai berikut.

1. Sikap ilmiah berkorelasi terhadap prestasi belajar IPA siswa kelas V SDN seKecamatan Kebumen tahun ajaran 2020/2021, nilai koefisien korelasi 0,567 maka tingkat korelasi kuat yaitu semakin tinggi sikap ilmiah siswa maka prestasi belajar IPA yang diperoleh semakin baik.

2. Kecerdasan emosional berkorelasi terhadap prestasi belajar IPA siswa kelas V SDN se-Kecamatan Kebumen tahun ajaran 2020/2021, nilai koefisien korelasi 0,528 maka tingkat korelasi kuat yaitu semakin tinggi kecerdasan emosional siswa maka prestasi belajar IPA yang diperoleh semakin baik.

3. Sikap ilmiah dan kecerdasan emosional berkorelasi terhadap prestasi belajar IPA siswa kelas V SDN se-Kecamatan Kebumen tahun ajaran 2020/2021, nilai koefisien korelasi 0,634 maka tingkat korelasi kuat yaitu semakin tinggi sikap ilmiah dan kecerdasan emlosional siswa secara bersama-sama, maka prestasi belajar IPA yang diperoleh semakin baik.

Adanya sikap ilmiah dan kecerdasan emosional yang tinggi akan membuat prestasi belajar siswa lebih optimal. Hasil tersebut dapat direkomendasikan bagi guru maupun calon guru dalam upaya peningkatan kualitas pembelajaran. Hal ini dapat dilakukan dengan cara meningkatkan faktor lain yang mempengaruhi prestasi belajar seperti, faktor internal dan faktor eksternal.

\section{DAFTAR PUSTAKA}

Adnyana, I. W. J., Suma, K., \& Suswandi, I. (2017). Kontribusi Motivasi Belajar, Kecerdasan Emosional, dan Kecerdasan Intelektual terhadap Prestasi Belajar Fisika. Jurnal Pendidikan Fisika Undiksha, Vol. 7, No. 2, halaman 42-52.

Azhari, S., Suastra, I. W., \& Sudiatmika, A. A. I. A. R. (2020). Hubungan antara Motivasi Belajar dan Sikap Ilmiah dengan Prestasi Belajar Fisika Siswa Kelas XI IPA SMA Negeri. Jurnal Pendidikan Fisika Undiksha, Vol. 10 No. 2, p-ISSN: 2599-2554 (Print), e-ISSN: 2599-2562 (online), halaman 91100.

Ebrahimi, M. R., Khoshsima, H., \& Zare-Behtash, E. (2018). The Impacts of EnhancingEmotional Intelligence on the Development of Reading Skill. International Journal of Instruction, 11(3), 573-586.

Eva, L. M \& Kusrini, M. (2015). Hubungan Kecerdasan Emosional dan Berpikir Kreatif terhadap Prestasi Belajar Matematika. Jurnal Formatif, 5(3): 245-256, ISSN: 2088-351x, halaman 245-256.

Fatonah, S \& Prasetyo, Z. K. (2014). Pembelajaran Sains. Yogyakarta: Ombak.

Goleman, D. (2016). Kecerdasan Emosional: Mengapa El lebih penting daripada IQ. Jakarta: Gramedia Pustaka Utama.

Kardi, W. I., Arcana, N., \& Rasana, R. (2013). Hubungan antara Kecerdasan Emosional dan Motivasi Belajar terhadap Hasil Belajar IPA Siswa Kelas V SDN Kelurahan Kintamani Tahun Pelajaran 2012/2013. Jurnal Mimbar PGSD Undiksha, Vol. 1, No. 1, halaman 1-10.

Khairawati, Rahayu, H., M., \& Setiadi, A., E. (2018). Analisis Korelasi Sikap IImiah dan Prestasi Belajar Siswa Di SMPN 3 Sungai Kakap. Pena Kreatif: Jurnal Pendidikan, 
Volume 7, Nomor 1, ISSN Online 2541-2264, ISSN Cetak 2089-3027, halaman 52 -6 .

Kusumastuti, F. A., Rombot, O., \& Ariesta, F. W. (2019). The Effect of STEM Integration on Primary School Students' Scientific Literacy. International Journal of Scientific \& Technology Research, Volume 8, Issue 12, ISSN 2277-8616, Halaman 1551-1553.

Lestari, K. E \& Yudhanegara, M. R. (2017). Penelitian Pendidikan Matematika. Bandung: PT Rafika Aditama.

Murugan, P Vel. (2019). A Study on Scientific Attitude of Elementary Teacher Education Students. Psychology and Behavioral Science International JournaL, Issn 24747688, Volume 11 Issue 1, page 001-006.

Suryani, I. (2016). Pengembangan Instrumen Penilaian Sikap Ilmiah pada Pembelajaran dengan Model Latihan Penelitian di Sekolah Dasar. Jurnal IImiah Mahasiswa Pendidikan Guru Sekolah Dasar. Vol. 3, No. 2, halaman 217-227.

Suryantini, P., Sujana, I. W., \& Wiarta. I.W. (2018). Korelasi antara Sikap Ilmiah dalam Belajar dengan Kompetensi Inti Pengetahuan IPA. Jurnal Penelitian dan Pengembangan Pendidikan. Vol. 2. Nomor 1, halaman 52-59.

Thaib, E. N. (2013). Hubungan antara Prestasi Belajar dengan Kecerdasan Emosional. Jurnal Ilmiah Didaktika, Vol. Xiii, No. 2, 384-399.

Ventini, M., Hartati, \& Sukardjo, M. (2018). Hubungan Kecerdasan Emosional dan Sikap terhadap Pelajaran Matematika dengan Hasil Belajar Matematika Siswa SMA Jakarta Timur. Jurnal Teknologi, Vol. 20, No. 2, halaman 167-180.

Wicaksono, A. G. \& Widyaningrum, R. (2016). Analisis Kontribusi Sikap Ilmiah dan Sikap Peduli terhadap Lingkungan terhadap Prestasi Belajar IImu Alamiah Dasar Mahasiswa Prodi PGSD Universitas Slamet Riyadi Tahun Akademik 2014/2015. Jurnal Widya Wacana, Vol. 11, No. 1, halaman 1-6.

Wulansari, K., R. (2014). Hubungan antara Kecerdasan Emosi dengan Kemampuan Pemecahan Masalah pada Remaja. Naskah Publikasi. Fakultas Psikologi Universitas Muhammadiyah Surakarta. 